\title{
Universal Service Policy in Vietnam: A Supply - Demand Perspective
}

\author{
Thai Do Manh, Morten Falch, and Salakpi von Simeon \\ Center for Communications Media and Information Technologies, \\ Aalborg University, Denmark \\ E-mail: \{dmt;falch;svys\}@cmi.aau.dk \\ Received 15 February 2016; \\ Accepted 14 April 2016

\begin{abstract}
Universal service provision is a key to bridge the digital divide. This paper provides an empirical examination of the Vietnamese universal policy introduced in 2015 for implementation up to 2020. Using the framework of King et al. (1994) the paper analyses the universal services policy in Vietnam as well as the policies of broadband development in South Korea and Japan in order to clarify the types of universal service initiatives made in these countries. Furthermore, the paper compares the universal service policy in Vietnam with the broadband development policy in South Korea and in Japan in order to evaluate whether the Vietnamese universal policy is efficient. The paper concludes with a discussion of how an effective universal policy can be designed.
\end{abstract}

Keywords: Universal services, broadband, policy, supply, demand.

\section{Introduction}

Information and communication technologies (ICT) in general and broadband technology in particular become still more important for the social and economic development at the national level. According to a World Bank study, every 10 percent increase in broadband penetration has led to an

Journal of NBICT, Vol. 1, 123-140.

doi: 10.13052/NBICT.2016.007

(C) 2016 River Publishers. All rights reserved. 
increase of 0.24 to 1.5 percent in economic growth (Kelly \& Rossotto, 2012). Nevertheless in many countries searching for remedies, the questions of how to transform fully the advantage of ICT into the growth of society and economy, and how to enhance the build out of broadband still remain. Previous research have agreed that the role of government policies is critical when it comes to stimulate penetration of broadband (Falch, 2007; Frieden, 2005; Hammond IV, 2005; Lee \& Chan-Olmsted, 2004; Lee et al., 2003; Picot \& Wernick, 2007; Samarajiva, 2000). However, no one-size-fits-all policy has been developed. Each country has pursued their own strategy taking country-specify social and economic conditions into account.

From the supply-demand angle, this paper will look at the universal service policy in Vietnam and the policy of broadband development in South Korea and Japan in order to identify the types of initiatives pursued in these countries. Furthermore, the paper compares these three countries in order to evaluate the Vietnamese policy and to identify additional possible policy measures.

Based on this, the paper will attempt to answer the following question:

Which types of policy should Vietnam introduce?

To answer this question, the paper applies the framework of King et al. (1994) in order to analyze the universal service policy being implemented in Vietnam as well as the broadband policies deployed in South Korea and Japan. The paper applies an demand-pull and supply-push model of government intervention for IT diffusion.

The definition of universal access and service (UAS) is very distinct from country to country. It is likely that each country has created a definition that is in line with its social, economic, and technological development. According to ITU, there are three fundamental characteristics of UAS: availability, accessibility, and affordability. The main target of UAS is to ensure that basic telecommunications services are accessible to individuals regardless of geography, gender, ethnicity, disabilities, or other factors. In this study, the term of UAS in Vietnam is understood as the provision of public telecommunication services, which include universal services as well as mandatory telecommunication services. Universal services are defined as voice telephony service, fixed broadband Internet access service, and terrestrial mobile communication service. The mandatory services include emergency calls ${ }^{1}$. Subsidies are provided for the provision of fixed line and terrestrial mobile communication services to low-income households.

\footnotetext{
${ }^{1}$ Decision no 1168 issued on 24th July, 2015 by the Prime Minister approving the Program on provision of public telecommunications services till 2020.
} 
Subsidies are also provided for fixed broadband Internet access to communes, hospitals, and schools over the whole country.

The paper uses qualitative methods to analyze secondary documents collected from the Vietnamese Ministry of Information and Communications (MIC) and the Vietnam Public Utility Telecommunication Service Fund (VTF), and some international organizations. Then the authors make a comparison to evaluate the universal services policy in Vietnam.

The paper is structured as follows: Section 2 presents the theoretical framework and research methods, Section 3 highlights the background for universal service provision in Vietnam; Section 4 shows policies promo ting universal services/broadband development in Vietnam, South Korea, and Japan; Section 5 analyses the results; and finally, Section 6 provides conclusions and some recommendations.

\section{Theoretical Framework and Research Method}

In their study, King et al. (1994) argued that information technology (IT) has been increasingly used in both developed and developing countries. To enhance further the application of IT, governments tend to facilitate the diffusion of IT. However, due to the absence of research on institutional factors, some of the appropriate national policies are uncertain and ambiguous (King et al., 1994).

Based on the perspective of the supply-push and demand-pull model, King et al. (1994) posit that an institution is any standing social entity and might exert influence and regulation over other social entities via supplypush and demand-pull force. In which the supply-push force comes from the production of the innovative product or process itself and the demand-pull force arises from the willingness of potential users to use the innovation. By combining perspective of supply and demand theory, and power of an institution (influence and regulation) they recommend six actions institutions can take in order to promote the diffusion of IT (Table 1):

1. knowledge building,

2. knowledge deployment,

3. subsidy,

4. mobilization,

5. standard setting, and

6. innovation directive.

Each type of these actions can address either the demand or the supply side. 
Table 1 Dimensions of institutional intervention (King et al., 1994)

\begin{tabular}{lll}
\hline & Supply-Push & Demand-Pull \\
\hline Influence & Knowledge building & Knowledge deployment \\
& Knowledge deployment & Subsidy \\
& Subsidy & Mobilization \\
& Innovation directive & \\
Regulation & Knowledge deployment & Subsidy \\
& Subsidy & Standards \\
& Standards & Innovation directive \\
& Innovation directive & \\
\hline
\end{tabular}

Knowledge building is undertaken to provide the scientific and technical knowledge base required to produce and exploit innovations, e.g., funding of universities and research;

Knowledge deployment is to stimulate the dissemination of new knowledge; A subsidy is support provided to innovators and users to defray the unavoidable costs or risks related to the innovation process and the diffusion of usage;

Mobilization basically means the encouragement of decentralized actors and organizations to think in a particular way with respect to an innovation, e.g., promotional and awareness programs or advertisement to support the use of innovations;

Standard setting is a form of regulation aimed at constraining options of decentralized actors and organizations in line with larger social or institutional objectives;

Innovation directive is a command to produce innovations, to use them, or to engage in some activity that will specifically facilitate production and/or use.

This paper is applying the framework with the supply and demand side in order to look at which actions Vietnam, South Korea, and Japan have taken as part of their ICT policy. Through a comparison of national policies, the paper evaluates the efficiency of the policy being implemented in Vietnam. Some lessons for Vietnam and developing countries in building up policies will be drawn.

The secondary data were mainly collected from the Vietnamese Ministry of Information and Communications (MIC) and the Vietnam Public Utility Telecommunication Service Fund (VTF). Some data were also gathered from reports of international organizations (ITU, the World Bank), nations and research findings of some papers. 
The analysis of Vietnam focuses on two ICT policy programmes: In 2006, Vietnam introduced the 'Program on the provision of public telecommunications services until 2010'. This program was completed in 2010. Recently, the government just issued another program, the 'Program on the provision of public telecommunications services until 2020 (Decision 1168 dated on July 24, 2015)'.

\section{Background in Universal Services in Vietnam}

Vietnam has carried out policies on universal services since the 1990s. However, since joining the World Trade Organization in 2006, the Vietnamese government has considerably adapted the universal service policy to meet the WTO's requirements.

The first universal service program was implemented from 2005-2010 (namely the Program on the provision of public telecommunications services towards 2010). The total budget of this program was approximately 210 million euros funded by a share of the annual revenue of the incumbent providers. This program made some significant achievements, the penetration rate for fixed lines increased to 16 percent at the end of 2010 (more than 6 times the penetration in 2005) and the penetration of internet subscribers increased to 0.32 percent in 2010 compared to 0.018 percent in 2004 (Report $74,2012)^{2}$.

Nevertheless, some targets of the program were not reached. A mere 55\% of communes throughout the country had a public internet access centre and only $40 \%$ of the households in unserved and underserved areas had a fixed-line (Report 74, 2012). The type of universal services provided was still modest. The majority of universal services were fixed voice and dial-up internet access or broadband internet access (Decision 43, 2006) ${ }^{3}$. The form of provision of universal services was completely implemented via 'order place' or 'plan assignment' imposed on incumbent operators, not by bidding or based on the market mechanism (Circular 05, 2006) ${ }^{4}$.

\footnotetext{
${ }^{2} \mathrm{MIC}$ 's report on the implementation of the Program on provision of public-utility telecommunications services until 2010.

${ }^{3}$ Decision no 43 dated November 2nd, 2006 by MIC Issuing the list of public-utility telecommunications services.

${ }^{4}$ Circular no 05 issued on November 4th, 2006 by MIC Guiding to implement the Program on provision of public-utility telecommunications services until 2010.
} 
In 2011, the second program on provision of universal services was already approved by the Prime Minister and would have been deployed in a five-yearinterval, from 2011 to 2015 (Decision 1643, 2011) ${ }^{5}$. However, the second was postponed and reformulated. On July 24th, 2015 the Prime Minister issued an additional program: Program on the provision of public telecommunications services until 2020.

\section{Policies Promoting Universal Services/Broadband Development}

In this section, the paper will use the framework of King et al. (1994) to analyze initiatives implemented in Vietnam, South Korea, and Japan.

\subsection{Vietnam}

After some years to adapt and build up the new program, 'on July 24th, 2015 the Program on the provision of public telecommunications services until 2020' was issued (here in after called Program 1168), a total of the budget is around 440 million euros. The program 1168 has been divided into five-partplans: Broadband Connection Plan, Emergency Connection Plan, Public Connection Plan, Institutes Connection Plan, and Digital Broadcast Connection Plan. Table 2 specifies the plans that Vietnam is implementing.

\subsubsection{On the supply side}

In order to enable the availability of telecommunication infrastructure for the provision of universal services, Vietnam has issued a variety of subsidies, such as subsidies for the development of infrastructure, and subsidies for development and maintenance of public internet access centres.

\section{Subsidies for development of infrastructure - the Broadband Connection} Plan:

Recognized the shortcomings of the precede program (Program on provision of public-utility telecommunications services until 2010) in terms of insufficiently supporting facility-based service providers in infrastructure

\footnotetext{
${ }^{5}$ Decision no 1643 issued on September 21st 2011 by the Prime Minister approving the program of provision of universal services period 2011-2015.
} 
Table 2 An overview of the program on the provision of public telecommunications services until 2020

\begin{tabular}{|c|c|c|c|c|c|}
\hline & $\begin{array}{l}\text { Broadband } \\
\text { Connection } \\
\text { Plan }\end{array}$ & $\begin{array}{l}\text { Emergency } \\
\text { Connection } \\
\text { Plan }\end{array}$ & $\begin{array}{l}\text { Public } \\
\text { Connection } \\
\text { Plan }\end{array}$ & $\begin{array}{l}\text { Institutes } \\
\text { Connection } \\
\text { Plan }\end{array}$ & $\begin{array}{l}\text { Digital } \\
\text { Broadcast } \\
\text { Connection } \\
\text { Plan }\end{array}$ \\
\hline Beneficiary & $\begin{array}{l}\text { Facility } \\
\text { based } \\
\text { service } \\
\text { Providers }\end{array}$ & Users & Users & $\begin{array}{l}\text { Schools, } \\
\text { hospitals, and } \\
\text { Commune } \\
\text { People's } \\
\text { Committees }\end{array}$ & $\begin{array}{l}\text { Poor } \\
\text { households }\end{array}$ \\
\hline Investor & $\begin{array}{l}\text { Government } \\
\text { and } \\
\text { facility- } \\
\text { based } \\
\text { service } \\
\text { Providers }\end{array}$ & Government & $\begin{array}{l}\text { Government } \\
\text { and } \\
\text { Telecom } \\
\text { Providers }\end{array}$ & Government & Government \\
\hline $\begin{array}{l}\text { Main } \\
\text { objective }\end{array}$ & $\begin{array}{l}\text { Mobile and } \\
\text { Fixed } \\
\text { Broadband } \\
\text { Network }\end{array}$ & $\begin{array}{l}\text { Access to } \\
\text { emergency } \\
\text { calls }\end{array}$ & Access & Access & $\begin{array}{l}\text { Access to } \\
\text { broadcasting }\end{array}$ \\
\hline
\end{tabular}

Source: Vietnamese Ministry of Information and Communication.

roll out ${ }^{6}$, and departed from the point of view that "infrastructure development incorporated with efficient, technological management will facilitate the provision of universal services in future" 7 hence, in the Broadband Connection Plan, Vietnam is to primarily concentrate on funding of telecom providers enabling them to establish a broadband infrastructure in communes, where they not yet have broadband facilities. The main objective of the plan is to provide broadband access in 99 percent of the communes in the whole nation that have power. Dwellers may access to fixed broadband internet connectivity via public internet access centres. The subsidization accounts for a major share of the total budget of the Program 1168 (up to 70 percent of the budget, approximately 300 million euros). The subsidization will be auctioned to select telecom providers to build out

\footnotetext{
${ }^{6}$ Because interest of the loan was not really attractive to telecom providers and did not help them to offset the investment cost in unserved and underserved areas. Thus, not many facility based service providers wanted to loan, the amount of money disbursed solely reached $25 \%$ of planned budget (Report on the implementation of the Program on provision of public-utility telecommunications services until 2010, MIC 2012).

${ }^{7}$ Project of formulating the Program on provision of public-utility telecommunications services towards 2020, MIC.
} 
infrastructure. Apparently, Vietnam in its agenda is to give a high priority in building up broadband networks, particularly in isolated and mountainous areas.

Subsidies for development and maintenance public internet access centres the Public Connection Plan:

Besides, the government is also to deploy the Public Connection Plan. The main objective of this plan is to enable users living in underserved and unserved areas to access to broadband internet services at public internet access centres (PIACs). By this plan, telecom providers will not only be equipped with facilities (computer sets, printers/scans, and tables) to set up 500 new PIACs, but also get financing for maintenance of all of the PIACs in under served and unserved areas (consist of 500 new PIACs).

It can be said that this is a remarkable change of the government policy with regard to subsidizations compared with those of the previous program (Program on the provision of public-utility telecommunications services until 2010). Previously the government only provided facility-based operators with loans at preferential rates for roll out of networks and financed them to sustain public telecommunication services centres. However, nowadays they will provide finance to build up new infrastructure and equip the PIACs with digital devices in order to encourage users to access.

However, some kinds of actions like Knowledge building, Knowledge deployment, Innovative directive, and Standards have not been addressed yet.

\subsubsection{On the demand side}

In addition to providing subsidies to telecom providers, the government is also to grant subsidies to stimulate demand among the population.

\section{Subsidies for demand - the Institutes Connection Plan:}

The first measure is the Institutes Connection Plan. Identified institutes such as schools, hospitals, and commune people's committees that have a high demand for broadband internet in training, education, health, and provision of public administration services. However, many of them located in rural and remote areas have not yet access to broadband internet, due to lack of affordable infrastructure. The Institutes Connection Plan will fund these institutes to install broadband internet connectivity. Moreover, the usage of broadband internet services in these institutes will be subsidized with a special monthly 
fee. Through the subsidization, the government hopes to enhance considerably demand for internet usage among the population.

In addition, the government will also subsidize poor households in their use of telephone or terrestrial mobile communication services via the Public Connection Plan. Having identified a decline in telephone subscriptions and a prevalence of mobile communication services, the government is to help poor households with payment of the monthly subscription fee to use a fixed line or a mobile communication service.

The government has not paid attention to introducing and improving endusers' IT knowledge or training them in the skills of using IT (Knowledge deployment and Mobilization) through deployment of any supply site or demand site initiatives.

\subsection{South Korea}

South Korea is one of the leading countries in terms of penetration of broadband in the world. The Korean government has played a critical role in implementing several national broadband development policies, liberalizing the telecommunication industry, and privatizing state-run companies (Lee \& Chan-Olmsted, 2004), and particularly in carrying out facilities-to servicesbased competition on broadband policy implementation (Choi, 2011).

In 1993, South Korea formulated a set of national policies on broadband internet information infrastructure (the Korean Information Infrastructure Plan-KII and the Cyber Building Certification system) to foster broadband roll out.

\subsubsection{On the supply side}

On the supply side, the Korean government has introduced a wide range of initiatives to stimulate investments in broadband facilities (Lee et al., 2003). For instance the government has partially subsidized facility-based service carriers to construct broadband networks (Subsidy) (Choudrie et al., 2003) and it has supported research institutes and universities in order to undertake research and development in broadband technologies (Knowledge building) (Choudrie et al., 2003). In addition, the government has facilitated competition by granting licenses to telecommunications operators and implementing the hands-off policy to deregulate the registration procedure. They have also required builders of large apartment complexes to install information and communication networks for residents (Lee \& Chan-Olmsted, 2004). 


\subsubsection{On the demand side}

On the demand side, South Korea stimulated the awareness of people about the benefit of broadband access by forming the 'Ten million people internet education project' (Mobilization) (Choudrie et al., 2003; Lee et al., 2003). In line with this policy, IT literacy programmes for groups of housewives, elderly, military personnel, farmers, and low-income families have been initiated. Particularly, housewives were targeted as the main sector due to their great influence on household purchases. The government has funded private IT/Internet institutes for training housewives and allowing them to take internet courses at an affordable price (Knowledge deployment) (Choudrie et al., 2003). Furthermore, in order to promote the broadband access platform in apartments and new buildings, in 1997, the Korean government introduced the Cyber Building Certificate system (Standards) (Choudrie et al., 2003). Accordingly, the government issued certificates for buildings with highspeed telecommunications capacity and ranked buildings according to their capacity.

Consequently, the average annual growth rate of high-speed internet in South Korea, in the period 1999-2001, reached 30 percent (Lee \& ChanOlmsted, 2004). Moreover, in February 2001, 57.3 percent of the Korean internet home users had access to broadband connections, whereas the United States had the second highest penetration of only $11.1 \%$ (Lee et al., 2003).

\subsection{Japan}

With regard to measures of Japan that enhanced the penetration rate of broadband, we based our research on the National strategy for the information society (the e-Japan Strategy) to examine their policy implementation. The strategy was clarified by five specific programs (e-Japan Priority Policy Program $)^{8}$ (Takada, 2003). It can be said that the e-Japan Strategy was an ambitious program that Japan anticipated being the world's most advanced IT nation within five years (Takada, 2003).

\footnotetext{
${ }^{8}$ They are Formation of the World's Most Advanced Information and Telecommunications Networks; Promotion of education and development of human resources; Facilitation of Electronic Commerce; Digitization of the Administration and Utilization of IT in Other Public Areas; and Ensuring of security and reliability over advanced information and telecommunication networks.
} 


\subsubsection{On the supply side}

The Japanese government issued various types of measures to foster the penetration rate of broadband infrastructure, such as:

(1) Providing low-interest loans, tax incentives, and loan guarantees to private telecommunication carriers for the construction of ultra-high speed network infrastructure in the program of Formation of the World's Most Advanced Information and Telecommunications Networks (Subsidy). (2) Installing PCs and providing broadband internet access to schools and 7,000 libraries, public halls across the nation in the program of 'Promotion of Education and Development of Human Resources' (Subsidy). (3) Promoting research and development in the program of Formation of the World's Most Advanced Information and Telecommunications Networks (Knowledge building). (4) Moreover, the government carried out a regulation reform in preventing and eliminating the anti-competitive behavior.

\subsubsection{On the demand side}

On the demand side, the government deployed almost three out of its five programs (the e-Japan Strategy) to stimulate demand for usage of ultrahigh speed internet, such as the Facilitation of Electronic Commerce, the Digitization of the Administration and Utilization of IT in Other Public Areas (Innovation directive), and the Promotion of Education and Development of Human Resources (Knowledge deployment). In which, the Facilitation of Electronic Commerce boosted the commerce transactions online that led to the shaping the e-marketplace (B-to-B) and net action markets (C-to-C). The Digitization of the Administration and Utilization of IT in Other Public Areas promoted the electronic applications in administration field. It enabled administrative procedures in public areas to be conducted without any geographic or time constrains, thereby contributing to increased comfort and convenience for people. Moreover, the Promotion of Education and Development of Human Resources enhanced IT education and educational content in schools. Besides, in order to improve IT skill for its citizens (managers of SMEs, consumers, women, farmers, and fishers) Japan delivered IT skill training courses targeted to train around 6 million attendants.

By implementing the e-Japan Strategy, Japan although is not among top countries in terms of penetration, but they are leading in the penetration of FTTH and relating to bandwidths offered (Falch, 2007).

Table 3 encapsulates measures that Vietnam, South Korea, and Japan were, and are deploying. 
Table 3 Summarizing measures applied by Vietnam, South Korea, and Japan

\begin{tabular}{lllll}
\hline & Supply-Push & & Demand-Pull & \\
\hline Influence & $\begin{array}{l}\text { Knowledge } \\
\text { building } \\
\text { Knowledge } \\
\text { deployment }\end{array}$ & SK, JP & $\begin{array}{l}\text { Knowledge } \\
\text { deployment }\end{array}$ & SK, JP \\
Subsidy & Subsidy & VN \\
Innovation & & Mobilization & SK \\
directive & & & \\
Knowledge & & Subsidy & \\
deployment & Subsidy & SK, JP, VN & Standards & SK \\
& Standards & & Innovation \\
directive & \\
& & & & \\
\hline
\end{tabular}

Note: SK-South Korea, JP- Japan, VN-Vietnam.

\section{Analysis}

In this section, we will make a comparison between Vietnam's measures with those of South Korea and Japan in order to examine whether the Program 1168 is effective.

Basically, the Vietnamese government introduced the Program 1168 with efforts of balancing on promoting both supply side (subsidizing facility based service providers for roll out of broadband network and development of PIACs) and demand side (funding institutes to use broadband internet service and poor households to use telephone or mobile communication service). The main objective is to enable citizens and institutes to get benefit from the advantage of telecommunication services. In the Program 1168, the government is to focus on the development of infrastructure (subsidization up to $70 \%$ of total budget). However, these efforts only focus on the roll out of broadband network, while measures to increase knowledge or skills of citizens don't seem to have been considered to be effective policy tools.

Lessons from the prior program (the Program on provision of public-utility telecommunications services until 2010 mentioned in Section 3) shows that, if users have had information about this program and had recognized the benefits in terms of low charges and access to the ICT applications they could receive, 
they would have used more telecommunications services and applied them in their business ${ }^{9}$.

Lee et al. (2003) posits that efforts have focused on the supply side. It is assumed that services will be developed once the broadband infrastructure has been established. Hence it is not necessary to take initiatives to stimulate demand. Youtie et al. (2007) point out that reducing the cost of technology does not ensure rise in demand from low-income households. Similarly, Choudrie et al. (2003) conclude that citizens must be prepared to use the new technologies and services so that they can benefit from the enhanced capabilities.

Furthermore, the government should pursue a variety of policy measures for creating Internet demands as well as networks. This conclusion is also consistent with the study of Falch (2007) and Long (2010). As Falch (2007) states that it is important to stimulate the demand side via content development and increasing ICT skills. And Long (2010) indicates that universal service policy should spend money in promoting applications in education, agriculture, and health information by local language as well as funding of rural IT training. Apparently, policy makers need to emphasize not only on infrastructure development but also on demand stimulation and upgrading of users' ICT skills.

On the other hand, as demonstrated in the Table 3 we can see that the deployment of a wide range of strategies, each contributing to the boom in the penetration of broadband in South Korea, was very successful. It was in this case critical to include actions that stimulated demand, and not just focus on the supply site (Choudrie et al., 2003; Lee et al., 2003). Likewise, though not becoming the leading country on broadband penetration, Japan by applying complex programs is also successful with regard to achieving a high broadband penetration rate within a short time (Falch, 2007) or satisfy the highest service quality in the world (Takada, 2003). This point of view is as well similar to the study of Jordana et al. (2005). In their research, Jordana et al. (2005) posit that more complex initiatives have more intense impacts than simple ones on the regional internet usage rate. This argument is supported by the study of Damsgaard \& Lyytinen (2001). Based on a study on the diffusion of electronic data interchange in Denmark, Finland and Hong Kong Damsgaard \& Lyytinen (2001) point out that standard setting,

\footnotetext{
${ }^{9} \mathrm{An}$ issue of this program was that the volume of telephone subscriptions that heen funded dropped considerably when the government stemmed subsidization. Because local users had not perceived the advantage of ICT (Report on the implementation of the Program on provision of public-utility telecommunications services until 2010, MIC 2012).
} 
mobilization, knowledge building, and knowledge deployment are the most prominent measures that an institution may facilitate the diffusion of electronic data interchange.

Whilst the Program 1168 is somewhat simple, the Vietnamese government is only to carry out subsidization measures both for telecom providers and users. They do not pay attention to increasing the knowledge and ICT skills of users (knowledge deployment and mobilization strategies) or funding research institutes, enterprises to research developing the content (knowledge building strategy). South Korea and Japan may be very good examples for Vietnam and other developing countries to study. There are of course some other important factors such as culture, geography, demography, competition, and the PC Bang model contributing to the diffusion of broadband in South Korea (Lee et al., 2003). Although Japan also needs to enhance further the development of applications and content (Takada, 2003). Nevertheless, governments generally take the leading role influencing other players by their measures (Choudrie et al., 2003). They may foster ICT development by articulating from the top a broad vision of what ICT can do for a nation and their citizens (Frieden, 2005). Thus, initial measures to strengthen the penetration of broadband and promote usage have to come from governments who are responsible for formulating policies.

\section{Conclusion}

By applying the framework of King et al. (1994), the paper indicates that complex initiatives that stimulate the diffusion of ICT are very crucial, particularly the balance between the demand side and the supply side in formulating universal services policy.

Subsidization for facility-based service providers to build up broadband infrastructure is indispensable. It ensures that the carriers can afford to invest and maintain their business in unprofitable areas. Moreover, providing finance to develop public internet access centres is also to facilitate local citizens' accessibility to broadband internet services easier.

On the other hand, in order to stimulate demand for broadband internet, Vietnam is also to fund schools, hospitals, and commune people's committee to set up internet connectivity and use these services with low charges.

Nevertheless, the subsidies are not likely to be really effective if users do not know the benefits of ICT, especially dwellers living in unserved and underserved have lack of knowledge of ICT. The Vietnamese government should diversely deploy the Program 1168. That means along with support 
for facility-based service providers, institutes, and users the government also needs to carry out other plans promoting demand, such as plans to improve the knowledge and ICT skills of users or develop applications in education, agriculture, and health information in local languages.

The research has also some limitations. Constrained number of countries compared in performance may not sufficiently stress the importance of applying complex actions or measures to increase knowledge and ICT skills. Future research should gather more other countries' policy initiatives to examine, particularly nations that have the same economic and social conditions.

\section{References}

[1] Choi, S. (2011). Facilities to service based competition, not service to facilities based, for broadband penetration: a comparative study between the United States and South Korea. Telecommun. Policy 35, 804-817. doi:10.1016/j.telpol.2011.08.003

[2] Choudrie, J., Papazafeiropoulou, A., and Lee, H. (2003). A web of stakeholders and strategies?: a case of broadband diffusion in South Korea. J. Inf. Technol. 18, 281-290. doi: 10.1080/0268396032000150816

[3] Damsgaard, J., and Lyytinen, K. (2001). The role of intermediating institutions in the diffusion of electronic data interchange (EDI): how industry associations intervened in Denmark, Finland, and Hong Kong. Inform. Soc. 17, 195-210. doi: 10.1080/01972240152493056

[4] e-Japan Priority Policy Program. (n.d.).e-Japan Priority Policy Program (March 29, 2001)

[5] Falch, M. (2007). Penetration of broadband services - the role of policies. Telemat Inform. 24, 246-258. doi: 10.1016/j.tele.2007.01.008

[6] Frieden, R. (2005). Lessons from broadband development in Canada, Japan, Korea and the United States. Telecommun. Policy 29, 595-613. doi: 10.1016/j.telpol.2005.06.002

[7] Hammond IV, A. S. (2005). Universal service: problems, solutions, and responsive policies. Federal Commun Law J. 57, 187-200.

[8] Jordana, J., Fernández, X., Sancho, D., and Welp, Y. (2005). Which Internet Policy? Assessing regional initiatives in Spain. Inform. Soc. 21, 341-351. doi: 10.1080/01972240500253509

[9] Kelly, T., and Rossotto, C. M. (2012). Broadband Strategies Handbook. The World Bank, Vol. 1. doi:/10.1596/978-0-8213-8945-4 
[10] King, J. L., Gurbaxani, V., Kraemer, K. L., Mcfarlan, F. W., and Yap, C. S. (1994). Institutional factors in information technology innovation. Inform. Syst. Res. 5, 139-169.

[11] Lee, C., and Chan-Olmsted, S. M. (2004). Competitive advantage of broadband Internet: A comparative study between South Korea and the United States. Telecommun. Policy 28, 649-677. http://doi.org/10.1016/j.telpol.2004.04.002

[12] Lee, H., O'Keefe, R. M., and Yun, K. (2003). The growth of broadband and electronic commerce in South Korea: contributing factors. Inform. Soc. 19, 81-93. doi: 10.1080/01972240309470

[13] Long, N. V. (2010). Study on Consumer Preference for Internet Service in Rural Area of Vietnam. Ph.D Thesis, Seoul National University, Seoul.

[14] Picot, A., and Wernick, C. (2007). The role of government in broadband access. Telecommun. Policy 31, 660-674. doi: 10.1016/j.telpol.2007. 08.002

[15] Samarajiva, R. (2000). Role of competition in institutional reform of telecommunications: lessons from Sri Lanka. Telecommun. Policy 24, 699-717. doi: 10.1016/S0308-5961(00)00057-4

[16] Takada, Y. (2003). Promoting broadband: the case of Japan. Workshop on promoting broadband, Genneva, Switzerland.

[17] Youtie, J., Shapira, P., and Laudeman, G. (2007). Supply, demand and ICT-based services: a local level perspective. Telecommun. Policy 31, 347-358. doi: 10.1016/j.telpol.2007.05.005

\section{Biography}

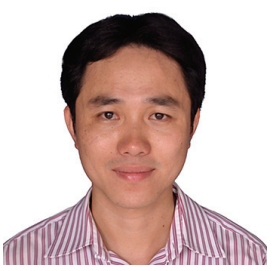

T. D. Manh is a PhD fellow at Communication, Media and Information Technologies (CMI), Department of Electronic Systems, Aalborg University Copenhagen, Denmark. He holds a bachelor in business administration in 1998 and master degree in economics in 2004. He has had many years of experience 
working in universal service field in Vietnam. Since 2014, he has researched into telecommunications policy, particularly in universal services relating to broadband internet. His main research focuses on looking for the ways to foster the penetration of broadband infrastructure in rural and mountainous areas in developing countries.

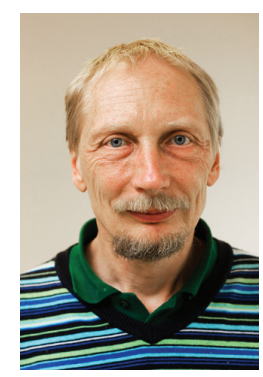

M. Falch is Associate Professor at Center for Communication, Media and Information Technologies (CMI) located at Aalborg University Copenhagen. He holds a bachelor in Mathematic, a master degree in economics and a Ph.D. and has since 1988 specialised in research on socio-economic issues related to Information and Communication technologies.

He has participated in 40 research projects in the telematics area more than a third of these have been funded by EU. He has also conducted a large number of consultancies for national and international organisations such as ITU, UNCTAD, the World Bank and the National Telecom Agencies in Denmark, Norway and Sweden.

He has authored almost 200 research publications including journal papers, book chapters and research reports and conference papers. $\mathrm{He}$ is Editor-in-Chief of International Journal of E-Services and Mobile Applications (IJESMA) published by IGI Global. He has organised international conferences for organisations like International Telecommunications Society (ITS) and European Communication Policy Research Organisation (EuroCPR). 


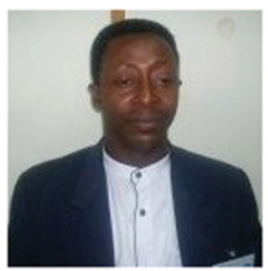

S. von Simeon is a PhD Student-Researcher in Information Communications Technology for Development (ICT4D) at Communication, Media and Information Technologies (CMI), Department of Electronic Systems, Aalborg University, Denmark. His academic background includes a Bachelor of Science degree in Computer Science and Statistics at University of Legon, Ghana, and post graduate certificates in Computer Applications in Management and Principles of Management Information Systems at USDA Graduate School, Washington D.C. USA: Management Information Systems at the University of Bonn, Germany. Advanced Networking Technologies at NIIT, India: Policy Formulation, Analysis and Implementation at MDPI in Swaziland, ICT4D Problem-Solution at Kobe Institute of Computing Graduate School of Information Technology, Japan and Certified Information System Auditor (CISA) - ISACA among others. He had his Masters in ICT at Aalborg University, Denmark. He has served as resource person/speaker in various local and international seminars/workshops/fora and trainings on ICT for Development.

He has over 25 years experience in research into and development of eServices. He has been with Ministry of Food and Agriculture since 1991 and doubles as Deputy Director of ICT and ICT Manager. His current responsibilities include the strategy, planning, policy formulation, implementation and execution of Information and Communication Technologies for Development (ICT4D) research, design and practice in Agriculture sector in Ghana. In my perspective as Policy Analyst regarding policy issues in the public domain, public policy analysis - the examination of components of public policy and the policy process. Most recently, he has been actively involved in EAgriculture programme for the Ministry of Food and Agriculture in Ghana. He has publications in the use of ICT $\backslash$ IT to his credit including ICT Implementation Policy Document for Ministry of Food and Agriculture. He is a member of Academia and LinkedIn platforms. He has recently presented a Conference paper at the Information Technology Seminar (ITS) Conference, 2016 in Ghana. In his spare time he loves listening to cool and jazz music, reading, soccer $\backslash$ lawn tennis and loves sight-seeing (travelling). 